\title{
International Race for Regulating Crypto-Finance Risks
}

\author{
A Comprehensive Regulatory Framework Proposal
}

Yaiza Cabedo*

\subsection{REGULATORY RESPONSES TO FINANCIAL INNOVATION FROM A REGULATORY COMPETITION PERSPECTIVE}

States are in continuous competition to attract business, wealth and innovation through the quality of their administration and courts and their capacity to provide specialised, innovative and efficient regulatory solutions to ensure a level playing field and an adequate level of protection for their citizens. ${ }^{1}$ In this international regulatory race, the US legal system was a pioneer in regulating new rights, such as civil rights, women's rights, environmental regulations or traffic safety rights - all successful regulatory innovations that other countries imported. The US administrative model was inspired by the German and English administrative law principles, and at a later time, the US functioning between the fifty states and the federal government also inspired the functioning of the European Union and globalisation through what we call the globalisation of law phenomenon. ${ }^{2}$

The European Union (EU), with its regulatory initiatives and the development of its own process for regional and global integration, also became progressively an essential element for global checks and balances, able to correct and prevent distortions to the US legal and federal principles, such as antitrust law and the control of monopolies, deeply entrenched in the political and legal tradition of economic federalism. ${ }^{3}$ The European Commissioner for Competition, Vestager,

I am grateful to Manuel Ballbé Mallol for his great support and valuable contribution to an earlier draft. The views expressed in this article are privately held by the author and cannot be attributed to the European Securities and Markets Authority (ESMA).

1 See Ballbé, M. ; Padrós, C. Estado competitivo y armonización europea. Ariel. Barcelona, 1997. See also Ballbé, M.; Cabedo, Y. La necesidad de administraciones reguladoras en Latinoamérica para prevenir los ataques especulativos, los riesgos financieros y la defensa de los consumidores. Revista del CLAD Reforma y Democracia. No 57. Caracas, October 2013.

= Ballbé, M.; Martinez, R. Law and globalization: between the United States and Europe in global administrative law. Towards a lex administrativa. Eds. Robalino-Orellana, J.; Rodriguez-Arana, J. Cameron May. 2010.

3 Ballbé, M.; Martinez, R. (2010). 
and the antitrust case against Google illustrates the EU as a countervailing power to limit US companies' malpractice. ${ }^{4}$

One of the most potent administrative innovations in the United States since its Constitution is the independent regulatory agency (or authority as it is referred to in the EU). While the "Constitution was designed to make lawmaking cumbersome, representative, and consensual[,] the regulatory agency was a workaround, designed to make lawmaking efficient, specialized, and purposeful' with fewer internal hierarchy conflicts and with pre-ordained missions. ${ }^{5}$

Wilson's presidency in the United States laid the foundations for an innovative decentralised system of independent regulatory agencies; the Massachusetts Board of Railroad Commissioners (1869) was the first of its kind. The Commission was formed to request information and issue recommendations without holding any enforcement power yet with capacity for publicity and admonition, which proved to be a more powerful antidote for corruption than force and compulsion. ${ }^{6}$ This system was reproduced at state and federal levels and across sectors, creating a new regulatory model (e.g., the Federal Trade Commission, created in 1914, or the Federal Reserve, created in 1913). ${ }^{7}$

President Roosevelt, when reforming financial markets after the 1929 crash, created the Federal Deposit Insurance Corporation in 1933 and the Securities Exchange Commission (SEC) in 1934. Similarly, President Obama, after the 2008 crisis caused by the deregulation of over-the-counter (OTC) markets, expanded the powers of the SEC and the Commodity Futures Trading Commission (CFTC) and set up the Consumer Protection Financial Bureau (CPFB) for the protection of financial consumers as part of its Dodd-Frank Act reform package. ${ }^{8}$

In the EU, the 2008 financial crisis fostered the creation of supranational and very specialised administrations for the early detection and prevention of financial risks, less bureaucratised bodies than the three EU co-legislators ${ }^{9}$ and able adapt quickly to new market challenges. The Single Resolution Board or the three European Supervisory Authorities - the European Securities and Markets Authority (ESMA) in charge of regulation and supervision of securities and financial markets, the European Banking Authority (EBA) for the supervising banking entities and the European Insurance and Occupational Pensions Authority (EIOPA) - are good examples. At the same time, the post-crisis reform also reinforced the EU decentralised regulatory model for financial markets, expanding the scope of action of each

4 See Commission fines Google $€_{1.49}$ billion for abusive practices in online advertising https://ec .europa.eu/commission/presscorner/detail/en/IP_19_1770

5 DeMuth, C. ; The regulatory state. National Affairs. Summer 2012.

6 Eastman, J. B. The public service commission of Massachusetts. The Quarterly Journal of Economics. Vol. 27. No. 4 (August, 1913). Oxford University Press.

7 Ballbé, M.; Martinez, R. (2010).

8 Ballbé, M., Cabedo, Y.; (2013).

9 The European Commission, Parliament and Council. 
EU Member State's independent regulatory agencies for the surveillance and regulation of financial products and markets.

From an international regulatory competition perspective, the system of independent regulatory agencies is a solid structure to enable countries to anticipate responses to risks and opportunities stemming from financial innovation and technological developments such as crypto-finance. Countries with the most advanced regulatory framework and most efficient and specialised regulatory bodies and courts will attract crypto-finance businesses and investors. ESMA's advice to the European Commission on ICOs and cryptocurrencies points out this competition between two financial blocs - the European Union and the United States - which may not be on the same page, with the European Union seeing mostly risks for regulators, investors and markets, and the United States being more open to the blockchain technology and crypto-assets. ${ }^{10}$

Indeed, states, far away from a passive-supervisory role, can and do play an essential role as precursors and innovation pioneers. Moreover, states can go well beyond the mere race for attracting business and rather contribute to generating new markets. ${ }^{11}$ Crypto-finance is yet another example of states' driven innovation, and one of the technological key components of blockchain, the unique 'fingerprint' or hash ${ }^{12}$ of each block of information in the chain, is generated using the standard cryptographic hashing functions invented by the US National Security Agency, ${ }^{13}$ an administration whose research is financed with public funds.

Ultimately, economic development and financial stability depend on states' capacity to anticipate needs and prevent emerging risks by reaching innovative solutions. DLT systems such as blockchain, thanks to their immutability of records, traceability and transparency, offer potential enhancements of legal, financial and administrative processes for private companies and also for governments. ${ }^{14}$ However, this transition to DLT-based systems requires new regulatory actors and legal changes. In this regulatory race, states can choose to join a race to the top and use

10 Brummer, C. EU reports on cryptoasset regulation could have global reverberations. Watchdogs urge EU-wide rules. 9 January 2019 www.rollcall.com/2019/o1/og/eu-reports-on-cryptoasset-regulationcould-have-global-reverberations/

${ }^{11}$ Mazzucato, M. The entrepreneurial state: debunking public vs. private sector myths. Anthem Press. London, 2013.

12 A hash provides a way to represent the bundle of transactions in a block as a string of characters and numbers that are uniquely associated with that block's transactions. De Filippi, P., Wright, A. Blockchain and the law: the rule of code. Harvard University Press. Massachusetts, 2018.

13 De Filippi, P., Wright, A. Blockchain and the law: the rule of code. Harvard University Press. Massachusetts, 2018.

14 For example, see Delaware law amendments to allow corporations to issue shares through blockchain in Reyes, C.L. Cryptolaw for distributed ledger technologies: a jurisprudential framework. Journal of Law Science and Technology. Spring 2018. Vol. 58 Issue 3. See also the Australian Stock Exchange transition to DLT for equity transactions https://cointelegraph.com/news/covid-19-forces-aussie-stockexchange-to-delay-dlt-overhaul-to-2023 
these technologies to compete in excellence or, on the contrary, go for a race to the bottom and compete in lenient and more permissive regulatory frameworks.

Innovative financial markets have always been a challenge and an opportunity for regulators from a competitive and regulatory perspective. The last paradigmatic example of a transformation of financial markets driven by the combination of financial innovation and lack of specific regulation or specialised surveillance bodies occurred with the rise of OTC derivatives markets, which consequently put at risk the global financial stability, ${ }^{15}$ with a cost of trillions of dollars for taxpayers around the world. ${ }^{16}$

\subsection{THE UNREGULATED OTC DERIVATIVE MARKETS AND THE TBTF ${ }^{17}$ :}

\section{LESSONS FROM A REGULATORY RACE TO THE BOTTOM}

In 1933, after the 1929 crash, Roosevelt introduced a package of regulatory measures to reform financial markets and increase their transparency and resilience. In addition, the SEC was created as a specialised independent regulatory agency for the surveillance and regulation of securities markets, and the Securities Exchange Act was enacted to regulate securities transactions, laying the foundations for the prosecution of insider trading. The SEC's A-1 form, the first disclosure document introduced, required issuers of stocks to provide

a narrative description of their businesses, details of corporate incorporation, management, properties, capital structure, terms of outstanding debt, the purpose of the new issue and associated expenses. It also demanded disclosure of topics not contained in listing applications, including management's compensation, transactions between the company and its directors, officers, underwriters and promoters, a list of principal shareholders and their holdings and a description of any contracts not made in the ordinary course of business. ${ }^{18}$

The SEC's success inspired the creation in 1974 of the CFTC, another specialised independent regulatory agency for the surveillance and regulation of futures markets.

Roosevelt's reform introduced principles for a regulated, more transparent and accountable capitalism, which provided financial stability and are still applicable

15 For further analysis on the causes of the crisis, see Lastra, R.M.; Wood, G. The crisis of 2007-09: nature, causes, and reactions. Journal of International Economic Law 13(3). See also Ballbé, M.; Cabedo, Y. (2013).

16 For figures on the bail-out costs of some EU financial institutions, see Ballbé, M.; Cabedo, Y. El ataque alemán deshaucia a España. 29 November 2012. In the United States, the Troubled Asset Relief Program initial budget amounted to $\$ 350$ billion.

17 Too Big to Fail banks.

18 Mahoney, P.G.; Mei, J. Mandatory versus contractual disclosure in securities markets: evidence from the 1930s. Working Paper, 23 February 2006. Cited in Brummer, C.; et al. What should be disclosed in an initial coin offering? 29 November 2018. Cryptoassets: Legal and Monetary Perspectives, Oxford University Press, Forthcoming. Draft 24 February 2019. 
today. However, starting from the late eighties in the $\mathrm{UK}^{19}$ and in the mid- to late nineties in the United States, new private markets in the form of OTC derivative markets emerged without administrative or judicial surveillance, introducing innovative and highly risky financial instruments that allowed betting on the future value of any underlying asset (stocks, interest rates, currencies, etc). These OTC markets have grown exponentially since 2000 , reaching $\$ 680$ trillion of notional value in $2008^{20}$ and becoming an epicentre of systemic risk, ${ }^{21}$ with New York and London concentrating 90 per cent of the market. This market transformation and its dramatic growth were possible due to a deregulatory race-to-the-bottom strategy.

In 1999, in the United States, the Gramm Act removed restrictions that prevented deposit-taking entities from acting as investment banks. ${ }^{22}$ In 2000, the Commodities and Futures Modernisation Act permitted corporations other than banks to trade as investment banks. In addition, it was established that the regulatory and surveillance capacity of the SEC and the CFTC would not apply to OTC derivatives markets. Indeed, all disclosure and identification requirements for regulated markets (stocks and futures) did not apply in OTC derivative markets, and instruments and behaviours that would have been considered a crime on Wall Street and any other regulated market, such as insider trading, were not prosecuted in OTC markets. Another restriction on banks' power, limiting the territorial scope of their banking services, ${ }^{23}$ was also lifted and generated a massive wave of mergers among financial institutions. While in 197012,500 small banks held 46 per cent of total US banking assets, by 2010, more than 7,000 small banks had disappeared and the few small banks still running only represented 16 per cent of all US banking assets. ${ }^{24}$ This is how banks became $\mathrm{TBTF}^{25}$ so big and powerful that they could easily capture the system - either through revolving doors or through information asymmetry (releasing technical information only favourable to their interests), ${ }^{26}$ and they succeeded in keeping regulators away.

19 In 1986, an amendment to the Game Act was approved to carve-out OTC derivatives. However, the boom of OTC derivatives markets took place later on, in 2000, once the United States had unwound all regulatory and supervisory checks for OTC derivative markets.

20 Bank for International Settlements. BIS quarterly review: international banking and financial markets development. December 2018.

${ }^{21}$ Cabedo, Y. OTC regulatory reform: risks of the clearing obligation from a competition perspective. Risk \& Regulation. London School of Economics, Centre for Analysis of Risk and Regulation. Summer 2016.

22 This fragmentation system had been implemented in 1933 with the adoption of the Glass-Steagall Act as a risk contention measure; in case an investment bank would fail, entities holding deposits would not be impacted.

23 US banks could not provide banking services beyond the limits of their home state. This was part of the Dual Banking System and was grounded on the US constitutional spirit of checks and balances and control of monopolies. In 1994, the Reagle Neal Act removed this territorial restriction allowing banks to merge with other banks in the other states.

24 Federal Reserve Bank of Dallas. Annual Report. 2011.

25 Or, as some authors like to say, 'too big to jail'.

26 Stigler, G. J. The theory of economic regulation. The Bell Journal of Economics and Management Science. Vol. 2 No. 1. Spring 1971. 
In the absence of administrative regulation and the lack of surveillance of OTC markets, the major OTC derivatives market players created the International Swaps and Derivatives Association (ISDA), ${ }^{27}$ which became the standards setter in OTC derivative markets, providing standardised documentation for OTC transactions and able to seduce governments to maintain OTC markets self-regulated. As ISDAs Chair said by then, 'Markets can correct excess far better than any government. Market discipline is the best form of discipline there is. ${ }^{28}$

After the 2008 financial crisis, the Special Report of the United States Congressional oversight panel concluded:

After fifty years without a financial crisis - the longest such stretch in the nation's history - financial firms and policy makers began to see regulation as a barrier to efficient functioning of the capital markets rather than a necessary precondition for success. This change in attitude had unfortunate consequences. As financial markets grew and globalised, often with breath-taking speed, the US regulatory system could have benefited from smart changes. But deregulation and the growth of unregulated, parallel shadow markets were accompanied by the nearly unrestricted marketing of increasingly complex consumer financial products that multiplied risk at every stratum of the economy, from the family level to the global level. The result proved disastrous. ${ }^{29}$

The regulatory response to prevent this from happening again was to regulate for disclosure with independent agencies and specialised regulation for OTC derivatives. International leaders agreed at the 2009 Pittsburgh Summit on a decentralised international regulatory framework; in the United States, the Dodd-Frank Act (2010) and in the EU the European Markets Infrastructure Regulation (2012) mandated the use of a Legal Entity Identifier or LEI (similar to an ID) for the identification of the parties to an OTC derivative contract and the obligation to report and make visible to competent authorities all OTC derivative transactions taking place in the market. In addition, systemic risk controls were adopted internationally, such as the clearing obligation for standardised OTC products and the need to provide guarantees when transacting bilaterally OTC derivatives. ${ }^{30}$

Initiatives for standardised transactional documentation for crypto-finance, such as the Simple Agreement for Future Tokens (SAFT), are being developed by market participants. Regulators should not miss the opportunity to engage since the start to introduce checks and balances and to further develop specialised knowledge while providing legal and contractual certainty to investors.

An argument used to advocate for self-regulation in OTC derivative markets was complexity. New technological developments such as blockchain and crypto-finance

27 ISDA gathers all major participants in OTC derivatives markets.

28 'Fools Gold' by Gillian Tett, Little Brown. 2009 p. 36. Cit. in Thomas, T. The 2008 global financial crisis: origins and response. 15th Malasyan Law Conference, 29-31 July. Kuala Lumpur. 2010.

29 Congressional Oversight Panel. Special report on regulatory reform. January 2009.

3० Cabedo, Y. (2016). 
are also highly complex systems. As Supreme Court Justice Louis Brandeis warned a century ago:

Business men have been active in devising other means of escape from the domain of the courts, as is evidenced by the widespread tendency to arbitrate controversies through committees of business organisations. An inadequate Remedy. The remedy so sought is not adequate, and may prove a mischievous one. What we need is not to displace the courts, but to make them efficient instruments of justice; not to displace the lawyer, but to fit him for his official or judicial task. And indeed, the task of fitting the lawyer and the judge to perform adequately the functions of harmonising law with life is a task far easier of accomplishment than that of endowing men, who lack legal graining, with the necessary qualifications. ${ }^{31}$

The emergence of new and innovative financial markets is an opportunity to apply lessons learned and prevent abuses arising from new and sophisticated cryptoassets. In addition, there is an increasing presence of tech giants in payment systems and crypto markets that will require new regulatory solutions. Big tech companies (e.g., Alibaba, Amazon, Facebook, Google and Tencent) have the potential to loom systemically relevant financial institutions very quickly; their business model builds on their large number users' data to offer a range of financial services that exploit natural network effects, generating further user activity. ${ }^{32}$ The Economist warns they can be too BAADD (big, anti-competitive, addictive and destructive to democracy), ${ }^{33}$ as they are a data-opoly ${ }^{34}$ with the potential to bring together new ways of tyranny.

\subsection{THE EMERGENCE OF CRYPTO-FINANCE: A RACE TO THE TOP OR A RACE TO THE BOTTOM?}

Crypto-finance uses DLT systems such as blockchain to trade assets or 'crypto-assets'. At its core, blockchain is a decentralised database maintained by a distributed network of computers that use a variety of technologies, including peer-to-peer networks, cryptography and consensus mechanisms. The consensus mechanism is the set of strict rules for validating blocks that makes it difficult and costly for any one party to unilaterally modify the data stored, ensuring the orderly recordation of information and enhancing security. ${ }^{35,36}$ Participants in the network are incentivised to proceed according to the protocol by a fee paid per block validated by the transaction originator. Miners select the unprocessed transactions and engage in

Brandeis, L.D. The living law. 1917, p. 468.

BIS. Big tech in finance. Opportunities and risks. Annual Report 2019.

How to tame the tech titans. The Economist. 18 January 2018.

Stucke, M.E. Should we be concerned about data-opolies? 2 Geo. L. Tech. Rev. 275. 2018.

De Filipi, P., Wright, A. (2018).

See Werbach, K.; Trust, but verify: Why the blockchain needs the law. Berkeley Technology Law Journal. Vol. 33 . 
computations until the first miner emerges with a valid proof-of-work which allows the miner to add a block of transactions to the blockchain, collecting the reward fees. ${ }^{37}$ The new blockchain is shared among the network of miners and other users, who verify the proof-of-work, the signatures and the absence of double-spending. If this new blockchain emerges as the consensus version, the majority of miners keep on adding to it. ${ }^{3}$

DLT systems are built upon a cryptographic system that uses a public key, publicly known and essential for identification, and a private key (similar to a password that enables to transfer assets) kept secret and used for authentication and encryption. ${ }^{39}$ Losing this password is equivalent to losing the right to access or move these assets. Blockchains are pseudonymous, and the private key does not reveal a 'real life' identity. ${ }^{4}$

How does owner $\mathrm{X}$ transfer a crypto-asset to $\mathrm{Y}$ ? X generates a transaction including $\mathrm{X}$ and Y's address and X's private key (without disclosing the private key). The transaction is broadcast to the entire network, which can verify thanks to X's private key that $\mathrm{X}$ has the right to dispose of the crypto assets at a given address. What makes the system safe is the impossibility of inferring the public key from the address or inferring the private key from the public key. Meanwhile, the entire network can derive the public key from the private key and hence authenticate a given transaction. ${ }^{41}$

By combining blockchains with 'smart contracts', computer processes which can execute autonomously, people can construct their own systems of rules enforced by the underlying protocol of a blockchain-based network. These systems create order without law and implement what can be thought of as private regulatory frameworks or lex cryptographica. ${ }^{42}$ As the CFTC Commissioner Quintez notes,

Smart contracts are easily customized and are almost limitless in their applicability. For example, individuals could create their own smart contracts to bet on the outcome of future events, like sporting events or elections, using digital currency. If your prediction is right, the contract automatically pays you the winnings... . This could look like what the CFTC calls a 'prediction market', where individuals use socalled 'event contracts', binary options, or other derivative contracts to bet on the occurrence or outcome of future events [which the CFTC generally prohibits in non-crypto markets]. ${ }^{43}$

37 The most commonly used are Proof of Work, Proof of Stake, Proof of Burn, Proof of Authority, Proof of Capacity and Proof of Storage (new ones are being introduced). Depending on which consensus mechanism is chosen, users will make different uses of computational logic on blockchain.

$3^{8}$ Auer, R. Beyond the doomsday economics of 'proof-of work' in cryptocurrencies. BIS Working Papers No 765 . January 2019 .

39 ESMA. Advice on Initial Coin Offerings and Crypto-Assets. 9 January 2019.

$4 \circ$ Schrepel, T. Collusion by blockchain and smart contracts. Harvard Journal of Law \& Technology. Vol. 33. Fall 2019.

$41 \quad$ ESMA (2019).

$4^{2}$ De Filippi, P.; Wright, A. (2018).

43 CFTC. Commissioner Brian Quintez at the 38th Annual GITEX Technology Week Conference. Public Statements \& Remarks, 16 October 2018. 
There are a wide variety of crypto-assets: the 'investment type' which has profit rights attached, like equities; the 'utility type' which provides some utility or consumption rights; and the 'payment type', which has no tangible value but the expectation to serve as means of exchange outside their ecosystem - and there are also hybrid types. ${ }^{44}$ Examples range from so-called crypto-currencies like Bitcoin to digital tokens that are issued through Initial Coin Offerings (ICOs). Crypto-finance is rapidly evolving since Bitcoin was launched in $2009,{ }^{45}$ and Central Banks are under pressure to improve the efficiency of traditional payment systems. ${ }^{46}$ According to the ESMA, as of the end of December 2018, there were more than 2, 050 crypto-assets outstanding, representing a total market capitalisation of around EUR 11obn - down from a peak of over EUR 7oobn in January 2018. Bitcoin represents half of the total, with the top 5 representing around 75 per cent of the reported market capitalisation. ${ }^{47}$

Blockchain-based finance is taking a bite out of public markets, as it enables parties to sell billions of dollars of cryptographically secured 'tokens' - some of which resemble securities - and trade OTC derivatives and other financial products by using autonomous and unregulated code-based exchanges. Moreover, 'these blockchain-based systems often ignore legal barriers supporting existing financial markets and undercut carefully constructed regulations aimed at limiting fraud and protecting investors'. ${ }^{8}$ Blockchain allows for anonymity in transactional relationships governed solely by the network protocols, where code is law. ${ }^{49}$ Moreover, crypto markets (like OTC derivative markets) are global and can avoid jurisdictional rules by operating transnationally. If not adequately regulated, crypto-finance can be used to circumvent the existing financial regulation and investors' protection safeguards to commit fraud and engage in money laundering, terrorist financing or other illicit activities.

Besides the obvious differences referred to the underlying technology, the emergence of crypto-finance represents, from a regulatory perspective, the emergence of the 'new over-the-counter market' with yet no specific regulation and no administrative surveillance. Instruments and behaviours that are no longer accepted neither in stock markets nor in the OTC derivative markets since their post-crisis reform are found in the new anomic crypto space.

The lessons learnt from the unregulated OTC derivative markets and how they became an epicentre of systemic risk should be applied to crypto-finance by regulating for disclosure and identification, setting up independent regulatory bodies with

44 ESMA. Advice on Initial Coin Offerings and Crypto-Assets. 9 January 2019.

45 ESMA. (2019).

$4^{6}$ A switch from public fiat toward private electronic money still leaves central banks unconvinced due to security, scalability and interoperability concerns. See Ward, O., Rochemont, S.; Understanding central bank digital currencies. Institute and Faculty of Actuaries. March 2019.

47 ESMA. (2019).

$4^{8}$ De Filippi, P.; Wright, A. (2018).

49 Lessig, L.; Code and other laws of cyberspace. Perseus Books, 1999. 
highly specialised officials and international coordination plans for establishing mechanisms for checks and balances that strike a careful balance between encouraging digital innovations and addressing underlying risks. ${ }^{50}$

\subsection{ATTEMPTS TO REGULATE CRYPTO-ASSETS}

The assignment of an object to one category (or none) initiates a whole cascade of further legal consequences, and as not all crypto-assets have the same features, not all of them need the same legal consideration. Crypto-currencies resemble currency in that they are exchanged 'peer-to-peer' in a decentralised manner, rather than through the accounting system of a central institution, but are distinguished from currency (i.e., cash) in that they are created, transferred and stored digitally rather than physically; they are issued by a private entity rather than a central bank or other public authority; and they are not 'legal tender.'. ${ }^{1}$

Most regulators first steps towards crypto consisted in the analogue application of existing regulations. While the SEC attempts to treat some crypto-assets as securities, Bitcoin and Ether are considered commodities. Both the head of the SEC and the chairman of the CFTC have said Bitcoin and Ether are exempt from Securities Law ${ }^{52}$ application and that they should be considered commodities under the Commodity Exchange Act. ${ }^{53} \mathrm{~A}$ recent decision from the trade court of Nanterre in France (Tribunal de Commerce Nanterre) ${ }^{54}$ qualifies for the first time the legal nature of Bitcoin, considering it as an intangible and fungible asset that is interchangeable - like a grain of rice or a dollar note - implying it has the features of money. ${ }^{55}$ In 2018, in Wisconsin Central Ltd. v. United States, the United States Supreme Court introduced a passing reference to Bitcoin, implying Bitcoin is a kind of money; Justice Breyer wrote "what we view as money has changed over time.... Our currency originally included gold coins and bullion... Perhaps one day employees will be paid in Bitcoin or other types of cryptocurrency'.

In relation to the tokens of an ICO, the SEC has been proactive in bringing ICOs within the scope of the Securities Act of 1933, mandating to comply with the extensive regulatory requirements in place when offering securities to the

50 Malady, L., Buckley, R. P., Didenko, A., Tsang, C. A regulatory diagnostic toolkit for digital financial services in emerging markets. Banking \& Finance Law Review, 34(1). 2018.

${ }^{51}$ Lastra, R. M., Allen, J. G. Virtual currencies in the Eurosystem: challenges ahead. Study Requested by the ECON Committee, European Parliament. July 2018.

52 Rooney, K. SEC chief says agency won't change securities laws to cater to cryptocurrencies, CNBC. com. 11 June 2018.

53 CFTC Release Number 8051-19: Chairman Tarbert Comments on Cryptocurrency Regulation at Yahoo! Finance All Markets Summit. 10 October 2019.

54 Decision of 26 February 2020.

55 Andrew Singer, French court moves the BTC chess piece. How will regulators respond? 15 March 2020 https://cointelegraph.com/news/french-court-moves-the-btc-chess-piece-how-willregulators-respond 
public. ${ }^{56} \mathrm{An}$ ICO is a pre-sell of tokens that allows a person to finance the creation of the infrastructure needed to develop an entrepreneurial project. Let's imagine we want to build a central infrastructure for the storage of data. To finance it, we issue a token. Users seeking storage would be incentivised to buy tokens to exchange them for storage space; other users would be incentivised to provide storage by the prospect of getting tokens. The designer of infrastructure would not have the property or the control over the infrastructure, but rather, it would be collectively run by the users. Nevertheless, providers would have incentives to do a good job - providing storage and maintaining the network - because if they want their tokens to be valuable, they need their network to be useful and well maintained. ${ }^{57}$

An ICO is to crypto-finance what an IPO (Initial Public Offering) is to the traditional or mainstream investment world, and both share the purpose of raising capital. However, they are not fully equivalent: in an IPO, a company offers securities to raise capital through middlemen (investment banks, broker dealers, underwriters), while in an ICO, a company offers digital tokens directly to the public. During the ICO boom of 2017 and 2018, nearly 1,000 enterprises raised more than $\$ 22$ billion ${ }^{5}$ while being largely unregulated. Yet they have also been associated with fraud, failing firms and alarming lapses in information sharing with investors. ${ }^{59}$

The SEC's investigation and subsequent DAO Report ${ }^{60}$ in 2017 was the first attempt to address the treatment of ICOs. The DAO (a digital decentralised autonomous organisation with open-source code, and a form of investor-directed venture capital fund) was instantiated on the Ethereum blockchain, had no conventional management structure and was not tied to any particular state, yet its token's sale in 2016 set the record for the largest crowdfunding campaign in history. The SEC's Report argued that the tokens offered by the DAO were securities and that federal securities laws apply to those who offer and sell securities in the United States, regardless of whether (i) the issuing entity is a traditional company or a decentralised autonomous organisation, (ii) those securities are purchased using US dollars or virtual currencies, or (iii) they are distributed in certificated form or through DLT. ${ }^{61}$

Under US law, securities are identified using the 'Howey Test' according to the Supreme Court ruling on SEC v. Howey ${ }^{62}$, which established that a security is a contract involving 'an investment of money in an enterprise with a reasonable expectation of profits to be derived from the entrepreneurial or managerial efforts of others'. Presumably, an investor buys tokens expecting an increase of the value,

Brummer, C.; Kiviat, T.; Massari, J. (2018).

Levine, M.; The SEC gets a token fight. Bloomberg. 28 January 2019.

Whirty, T., Protecting innovation: the kin case, litigating decentralization, and crypto disclosures. 4 February 2019 https:/www.alt-m.org/2019/o2/o1/protecting-innovation-the-kin-case-litigatingdecentralization-and-crypto-disclosures/

59 Brummer, C.; Kiviat, T.; Massari, J. (2018).

6o See SEC. Investigative report concluding dao tokens, a digital asset, were securities. Release. 2017.

${ }^{61}$ SEC. (2017).

62 SEC v. W. J. Howey Co. et al. 27 May 1946. 
however, the reasonable expectation of profits derived from the efforts of others is more complex to analyse, as it varies case by case. ${ }^{63}$

In the $\mathrm{EU}$, the definition of securities is less straightforward, where the term is defined differently in EU languages, against the background of national legal systems. Even harmonised definitions of securities such as those found in MiFiD, the Market Abuse Directive 2003/6/EC and the Prospectus Directive 2003/71/EC appear susceptible to different interpretations among Member States. ${ }^{64}$

Parangon and Airfox ICO's ${ }^{65}$ were the first cases where the SEC imposed civil penalties for violation of rules governing the registration of securities. Both issuers settled the charges and agreed to return funds to harmed investors, register the tokens as securities, file periodic reports with the SEC and pay penalties of \$250,000 penalties each. The SEC also initiated an inquiry into the ICO launched by Kik Service (which owns the messaging app Kik with over 300 million users worldwide ${ }^{66}$ ) and raised $\$ 100$ million $^{67}$ in 2017 selling a crypto-asset called Kin. ${ }^{68}$ Instead of settling, Kik responded to the SEC by defending Kik as a currency or 'utility token', designed as a medium of exchange within Kin's ecosystem, and citing that currencies are exempted from securities regulation. However, SEC regulators seek an early summary judgment against the firm, arguing the company was aware of issuing securities and had also assured investors the tokens could be easily resold. This case is relevant because if Kik carries on with its argumentation, the final decision would further clarify the boundaries of securities and currencies.

Despite the need for specific regulation for crypto-assets, fraud still remains fraud regardless of the underlying technology. In the action against 'Shopin', 69 the SEC alleged that the issuer, Shopin, and its CEO conducted a fraudulent and unregistered offering of digital securities, where tokens would raise capital to personal online shopping profiles that would track customers' purchase histories across numerous online retailers and link those profiles to the blockchain. However, Shopin allegedly never had a functioning product, and the company's pivot to the blockchain only resulted from its struggles to stay in business as a non-blockchain business. ${ }^{70}$

63 See US Securities and Exchange Commission. Framework for 'investment contract' analysis of digital assets. 3 April 2019.

${ }^{6}$ Lastra, R. M.; Allen, J. G. (2018).

${ }_{5}$ SEC. Two ICO issuers settle SEC registration charges, agree to register tokens as securities. Press release. 16 November 2018.

66 Whirty, T. (2019).

${ }_{67}$ Morris, D. Z.; How Kik's looming SEC fight could define Blockchain's future. Breakermag. 30 January 2019.

68 SEC v. Kik Interactive. US District Court Southern District of New York Case No. 19-cv-5244. 04/o6/ 2019.

69 SEC v. Eran Eyal and United Data, Inc. doing business as 'Shopin', Case 1:19-cv-11325, filed 11 December 2019.

70 Nathan, D.; Fraud is fraud - sales of unregistered digital securities resemble classic microcap fraud. JDSupra, 18 December 2019 . 
Qualifying crypto-tokens as securities instead of working on customised regulatory solutions for crypto-assets risks failing to provide an adequate level of protection. In a decentralised model, where the entrepreneur does not aim to keep control over the network, but rather build it to release it, if it is required to furnish financial statements and risk factors about the enterprise to potential investors (as for securities), then these financial statements will only show some expenses and no revenues for the first quarters and, once the infrastructure is built, nothing forever, which does not serve the purpose of protecting investors..$^{71}$

\subsection{PROPOSAL FOR A COMPREHENSIVE ADMINISTRATIVE FRAMEWORK FOR CRYPTO-FINANCE}

\subsubsection{A Crypto-Finance Specialised Regulation}

As illustrated by the cases presented and the attempts of financial regulators to bring crypto-assets under some of the existing regulations, new financial products and new forms of fraud and abuse involving crypto-assets justify a renewed demand (as following the stock market crash of 1929 or the 2008 financial crisis) for specialised crypto regulation and preventive action that enables investors to make betterinformed capital allocation decisions and reduce their vulnerability to wrongdoers.

Regulatory action requires a full understanding of the specific characteristics of financial products based on DLT systems. Moreover, the determinants of utility token prices are not the same as in traditional securities like stocks and bonds, and therefore financial requirements on traditional securities fail to provide the kind of useful information an investor needs when investing in crypto-assets. It is in the general interest to set up standards for the quality of the information to make investors less vulnerable to scams and allow investors to decide based on economic fundamentals, instead of driven by factors such as popularity and social media marketing, as is the case for ICO investment according to academic studies. ${ }^{72}$

Designing a specialised disclosure framework that considers the specific characteristics of crypto-finance requires more than just extending an existing regulatory regime to a new asset class, but it does not require starting from scratch. One of the key aspects when designing regulations for crypto is how to identify who is responsible for ensuring that activity on the blockchain complies with the law. As the CFTC Commissionaire Brian Quintez notes ${ }^{73}$ in the past, the CFTC has supervised derivatives markets through the registration of market intermediaries. Indeed, much of the CFTC's regulatory structure for promoting market integrity and protecting customers revolves around the regulation of exchanges, swap dealers, futures commission merchants, clearinghouses and fund managers, and we need to

${ }^{71}$ Brummer, C.; Kiviat, T.; Massari, J. (2018).

72 Brummer, C.; Kiviat, T.; Massari, J. (2018).

73 CFTC. Commissioner Brian Quintez. (16 October 2018). 
find new ways to preserve accountability in the disintermediated world of blockchain.

In addition, new financial service providers using DLT have entered the crypto financial market and may well require different regulatory treatment than traditional banks or non-bank financial institutions. The rapid growth of Big-Tech services in finance can enhance financial inclusion and contribute to the overall efficiency of financial services. Conversely, given large network effects and economies of scale and scope, Big Tech represents a concentration risk and could give rise to new systemic risks. These particularities need to be specifically addressed in the regulation. ${ }^{74}$

The SEC has named Valerie Szczepanik Senior Advisor for Digital Assets and Innovation, the first 'Crypto-Tsar' ${ }^{75}$ Szczepanik is optimistic about boosting the cryptocurrency market through better regulation. She highlights the importance of taking an initial principles-based approach towards new technologies while following and studying them closely to avoid a new precipitous regime. Acknowledging the international regulatory competition aspect at stake, even if some companies might go outside the United States in search of more lenient regulatory regimes - in her words - the real opportunity is with companies that abide by the stronger rules: "There are benefits to doing it the right way. And when they do that they will be the gold standard. ${ }^{76}$ Allegedly, SEC's strategy for crypto-finance is looking towards a race to the top.

As G20 leaders agreed on a regulatory reform to increase transparency in OTC derivative markets and prevent future crises at the 2009 Pittsburgh Summit, ${ }^{77}$ a joined international effort to regulate crypto-finance defining key principles would serve as the basis for establishing a decentralised regulatory framework for disclosure and for a coordinated surveillance of crypto-finance markets. In the same line, the International Organization of Securities Commissions (IOSCO) is working on key considerations to regulate crypto-assets, ${ }^{78}$ ensuring minimal coordination without being prescriptive and allowing competent authorities to implement their own strategies to reach common goals, and the FATF, the global money laundering and terrorist financing watchdog, issued guidance for monitoring crypto-assets and service providers. ${ }^{79}$ More needs to be done in this area.

74 Frost, J., Gambacorta, L., Huang, Y., Shin, H., Zbinden, P.; BigTech and the changing structure of financial intermediation. BIS. April 2019.

75 SEC. SEC Names Valerie A. Szczepanik Senior Advisor for Digital Assets and Innovation. Press release. 2018-102.

76 Dale, B. SEC's Valerie Szczepanik at SXSW: Crypto 'Spring' Is Going to Come. Coindesk.com. 15 Mars 2019.

77 G20 Leaders Statement: The Pittsburgh Summit. 24-25 September 2009.

$7^{8}$ See OICV-IOSCO. Issues, risks and regulatory considerations relating to crypto-asset trading platforms. February 2020. See also a compilation of Regulators' Statements on Initial Coin Offerings.

79 FATF. Guidance on a risk-based approach to virtual assets and virtual asset service providers. June 2019. 


\subsubsection{An Independent Regulatory Agency Specialised in Crypto-Finance to Foster Innovation within a Safe Environment}

Regulatory agencies represent an independent regulatory power, more effective in solving new situations and preventing emerging risks thanks to its less bureaucratised structure combined with a high degree of expertise and specialisation among its officers. These agencies can adopt regulation and recommendations, yet in some cases, they lack the most stringent enforcement and punitive tools. ${ }^{80}$ Nevertheless, guidance and recommendations can have a strong effect in shaping market participants' behaviour and can trigger peer-pressure mechanisms that intensify the agency's impact.

Notably, in the case of financial institutions, which are in constant interaction with the regulator, compliance with guidelines and recommendations has a greater impact because, on the one hand, regulatory agencies have licensing capacity, which is a powerful inducement to comply with guidance pronouncements. On the other hand, this continuous interaction between financial entities and agencies 'facilitates regulators' ability to retaliate on numerous dimensions through supervision and examination, in addition to their ability to bring enforcement actions for noncompliance with a specific policy' ${ }^{81}$ An agency overviewing crypto-finance should seek a constant interaction relationship with its supervised entities.

In addition, agencies are also a guarantee for transparency and market participation in the policy-making process. The US Administrative Procedure Act establishes that agencies' rule-making requires three procedural steps: information, participation and accountability. ${ }^{8}$ The EU agencies or authorities apply the equivalent public consultation procedure. In addition, there is an extra step envisaged for the $\mathrm{EU}$ agencies that mandates the inclusion of a costs and benefits analysis for each proposed regulatory measure. As Professor Roberta Romano highlights, this participative administrative procedure is linked to the political legitimacy of rule-making, given its management by unelected officials. Public participation 'can illuminate gaps in an agency's knowledge and provide an understanding of real-world conditions, as well as assist an agency in gauging a rule's acceptance by those affected'. ${ }^{3}$

James M. Landis, advisor to President Roosevelt and one of the designers of the post-crash regulations, understood that market stability should come from the creation of agencies in charge of monitoring business day-to-day life. Leaving all control to Courts through judicial review of cases did not allow for precautionary

8o In the EU, enforcement powers remain with national authorities and the ESAs are mainly tasked with ensuring supervisory convergence. In specific cases, the ESAs are direct supervisors (e.g., ESMA in relation to trade repositories or credit-rating agencies).

81 Romano, R. Does agency structure affect agency decisionmaking? Yale Journal on Regulation. Vol. 36,2019

82 Kerwin, C. M.; Furlong, S. R. Rule-making: how government agencies write law and make policy, 53 2011. Cit in Romano (2019).

83 Romano (2019). 
and preventive measures. Moreover, Courts and judges cannot carry out the constant task of following and analysing market trends as a dedicated agency can do. Landis asserted in The Administrative Process, published in 1938, that

the administrative process is, in essence, our generation's answer to the inadequacy of the judicial and legislative processes. It represents our effort to find an answer to those inadequacies by some other method than merely increasing executive power. If the doctrine of the separation of power implies division, it also implies balance, and balance calls for equality. The creation of administrative power may be the means for the preservation of that balance.

In addition,

efficiency in the processes of governmental regulation is best served by the creation of more rather than less agencies'. Administrative agencies should by all means be independent and not be simply an extension of executive power or of legislative power. This view is based upon the desire of obtaining supervision and exploration with 'uninterrupted interest in a relatively narrow and carefully defined area of economic and social activity. ${ }^{84}$

When speaking about an independent and specialised agency for cryptofinance, we do not necessarily imply the creation of new agencies from scratch. On the contrary, it proves more beneficial to build on the reputation of an existing specialised authority that is already known by the market, which broadens its scope to create a special arm or body within its remit and recruits crypto experts to focus exclusively on finding regulatory solutions to be applied in the crypto field. The LabCFTC, for instance, is set up to bring closer the Washington regulator (historically focused on commodity markets rather than digital assets) and Silicon Valley. The new director of LabCFTC, Melissa Netram, comes from the software company Intuit and illustrates CFTC Chairman Tarbert's philosophy that you 'can't really be a good regulator unless you are hiring people who actually know and understand these markets'. ${ }^{85}$

Crypto-finance also introduces new mechanics that can translate into new risks of collusion, which need to be understood and specifically addressed. Collusion needs trust between market players and blockchain can play a key role in this respect by allowing more cooperation between the players. The question then becomes whether blockchain can be used to set up a system of binding agreements, and accordingly, to change the game into a cooperative collusive one. Combined with smart contracts, blockchain makes colluders trust each other because the terms of the agreement are immutable. Competition and antitrust agencies' task is to create a prisoner's dilemma in which each player shares the same dominant strategy: to

84 Landis, J. M. The administrative process. Yale University Press, $193^{8}$.

85 CFTC Release 8051-19 (2019). 
denounce the agreement. Blockchain can help the players to build a reserve of trust, which in turn requires a greater effort from competition agencies. ${ }^{86}$

\subsubsection{Regulatory Sandboxes}

A regulatory sandbox is a scheme set up by a competent authority that provides regulated and unregulated entities with the opportunity to test, pursuant to a testing plan agreed and monitored by the authority, innovative products or services related to the carrying out of financial services. ${ }^{87}$ Sandboxes are an important cooperation mechanism that allows entrepreneurs to develop their projects while avoiding uncertainty regarding the applicable regulatory framework, and they provide regulators the knowledge and insights they need to prepare well-balanced regulation. As noted by the Basel Committee on Banking Supervision (BCBS), sandboxes may also imply the use of legally provided discretions by the relevant supervisor. ${ }^{88}$

As Judge Louis Brandeis said in the context of the creation of one of the Federal Trade Commission, knowledge and understanding must come before publicity and regulation:

You hear much said of correcting most abuses by publicity. We need publicity; but as a pre-requisite to publicity we need knowledge. We must know and know contemporaneously what business - what big businesses - is doing. When we know that through an authoritative source, we shall gone very far toward the prevention of the evils which attend the conduct of business. ${ }^{89}$

The sandbox concept, as a decentralised system of experimentation, plays a key role for administrative and regulatory innovation. Judge Brandeis theorised this concept in New State Ice Co. v. Liebmann: 'It is one of the happy incidents of the federal system that a single courageous State may, if its citizens choose, serve as a laboratory; and try novel social and economic experiments without risk to the rest of the country. ${ }^{90}$ This analysis advocates for administrative decentralisation as a foster of innovation. Decentralisation allows for experimenting with creative solutions in controlled spaces (or sandboxes) without endangering the global stability, and when other jurisdictions see merit in an innovation, they will then implement it without risk. This, in essence, is the same spirit inspiring crypto sandboxes.

Among other cases, the UK FCA set up a regulatory sandbox consisting of a controlled environment to test and issue securities using blockchain so the FCA

86 Schrepel, T. (2019).

87 See European Supervisory Authorities. Report on FinTech: Regulatory sandboxes and innovation hubs. JC 2018-74.

88 European Supervisory Authorities. (2018).

89 Brandeis, L. The regulation of competition versus the regulation of monopoly by Louis D. Brandeis. An address to the Economic Club of New York, 1 November 1912. Cited in Ballbé, M.; Martinez, R. (2010).

$90 \quad$ New State Ice Co. v. Liebmann, 285 US 262, 311 (1932) (Brandeis, J., dissenting). 
and the firms learn about the impact of current regulations on new financial products. However, at this stage, one could argue a 'sandbox is no longer an instrument for mutual learning only, but that it is becoming an original device for regulatory design where the FCA "swaps" with firms the accreditation of digital products in the UK financial market for influence in shaping the algorithms in a way which is more investor-friendly. Arguably, this strategy is producing a form of winwin regulation'. ${ }^{91}$

From an international regulatory competition perspective, FCA's strategy is also instigated by concerns about firms flying to offer digital securities in a more permissive market, while for a firm, being admitted to the sandbox represents an opportunity to be formally accredited by the FCA, which opens the door to one of the largest markets around the world. According to FCA, bespoke safeguards were put in place where relevant, such as requiring all firms in the sandbox to develop an exit plan to ensure the test can be closed down at any point while minimising the potential detriment to participating consumers..$^{92}$ This collaborative strategy is already paying off, and the UK is currently ahead in authorising electronic platforms to offer crypto derivatives, such as CFDs, ${ }^{93}$ putting certain activities under the regulator's radar. Nevertheless, the FCA had warned in 2017 that 'cryptocurrency CFDs are an extremely high-risk, speculative investment. You should be aware of the risks involved and fully consider whether investing in cryptocurrency CFDs', ${ }^{94}$ and consistent with this warning, it is to be expected that FCA, before granting authorisation to platforms trading crypto-CFDs, has implemented adequate investor's protection safeguards and enforcement procedures.

\subsubsection{The Principle of Judicial Deference in Favour of Independent Agencies' Interpretation}

The United States has long discussed the doctrine of the 'deference principle', which states courts should show deference in favour of specialised agencies (by dint of their expertise) when interpreting the ambiguity of a statute or law. As Cass Sunstein ${ }^{95}$ notes, the deference principle is a two-step approach, ${ }^{96}$ as established in

${ }^{91}$ Mangano, R.; Recent developments: The sandbox of the UK FCA as win-win regulatory device? Banking and Finance Law Review, Vol. 34, No. 1. December 2018.

$9^{2}$ UK, Financial Conduct Authority, Regulatory sandbox lessons learned report FCA, 2017. Cited in Mangano, R. (2018).

93 It is the case, for example, of $\mathrm{B}_{2} \mathrm{C}_{2}$, an electronic OTC trading firm and crypto liquidity provider, authorized by the FCA to offer OTC derivatives on cryptos. See Khatri, Y. UK firm gets regulatory green light to offer crypto derivatives. Coindesk.com. 1 February 2019.

94 FCA Public statement. November 2017.

95 Legal scholar and former Administrator of the Office of Information and Regulatory Affairs for the Obama administration.

96 Solum, L.B.; Sunstein, C. Solum, L. B.; Sunstein, C. R. Chevron as construction. Preliminary draft 12 December 2018. 
Chevron v. NRDC; 97 Courts must apply the deference principle to agency interpretations referred to legal texts when the provisions are ambiguous or unclear, so long as such interpretation is reasonable (in the sense that it is reasonable according to the agency's remit to interpret on that matter).

This case is fundamental in the recognition and delimitation of power of independent administrative agencies. It confirms that specialisation of officers in these agencies should prevail over Courts' judgments when it comes to interpreting statutory principles. For a subject as complex as crypto-finance, this deference principle in favour of the specialised agency would ensure better judgments and represents a precious asset in the international race between jurisdictions for becoming a financial crypto-hub.

\subsubsection{An Activist Agency: The Case of the Consumer Financial Protection Bureau (CFPB)}

Harvard Law Professor and Senator Elizabeth Warren has fiercely advocated for the creation of a specialised agency for the protection of financial consumers and for the introduction of disclosure requirements regarding credit and loans. Robert Shiller, who received the Nobel Prize in Economy, noted that

in correcting the inadequacies of our information infrastructure, as outlined by Elizabeth Warren, would be for the government to set up what she calls a financial product safety commission, modeled after the Consumer Product Safety Commission .... to serve as an ombudsman and advocate. It would provide a resource for information on the safety of financial products and impose regulations to ensure such safety... The National Highway Traffic Safety Administration maintains data on highway and motor vehicle safety and statistics on accidents. In the same way, we must fund a government organization empowered to accumulate information on the actual experience that individuals have with financial products and the 'accidents', rare as well as commonplace, that happen with them - with an eye toward preventing such accidents in the future..$^{8}$

The Dodd-Frank Act mandated the creation of the Consumers Financial Protection Bureau (CFPB) to protect consumers from unfair, deceptive or abusive practices, arming people with the information they need to make smart financial decisions, by empowering, educating and following a very dynamic (activist) strategy. The CFPB consolidated in one agency functions that had previously been allocated across seven federal agencies. To ensure independence, the CFPB was given a comparatively anomalous autonomous structure for a US administrative agency. It is organised analogously to a cabinet department in that it has a single director, but in contrast, the CFPB director has statutory removal protection. The 
agency is further independent of the executive by location, as it was placed within the Fed System. However, Fed Board governors may not intervene in the CFPB's affairs; review or delay implementation of its rules; or consolidate the bureau, its functions or its responsibilities with any other division. Also, a feature that is unique to the CFPB is its funding arrangement: it is independent of both Congress and the president, for it is not subject to the annual appropriations process. The director sets his/her own budget, which is funded by the Fed (capped at 12 per cent of the Fed's total operating expenses). Although the CFPB director must file semi-annual reports with Congress, there is minimal leverage that Congress holds to influence the agency, given its lack of budgetary control - which is a key disciplining technique. 99

The reaction of major market participants to an agency with such a degree of independence was categorical, as Warren condemned in 2009:

The big banks are storming Washington, determined to kill the CFPB. They understand that a regulator who actually cares about consumers would cause a seismic change in their business model: no more burying the terms of the agreement in the fine print, no more tricks and traps. If the big banks lose the protection of their friendly regulators, the business model that produces hundreds of billions of dollars in revenue - and monopolizes profits that exist only in noncompetitive markets - will be at risk. That's a big change. ${ }^{100}$

Pressure was such that although President Obama had first thought of Warren as the director of the agency, he needed to step back and look for another possible candidate with a lower profile in this matter.

There have been continuous efforts by opponents of the CFPB to restructure the agency, and the Republican House under Trump's administration passed a bill to make the CFPB more accountable. (What are they scared of?) The CFPB is an example of a quasi-activist agency dynamic and very specialised in protecting financial consumers' rights - a model that shall be emulated in other jurisdictions and whose strategies should inspire the creation of an activist agency for cryptofinance that not only monitors but most importantly makes information accessible to financial consumers in intelligible ways. This model is enough dynamic and participative to have forums that are constantly warning about new risks associated with crypto-assets, scams or any relevant information almost in real time.

\subsubsection{Administrative Judges Specialising in Crypto-Finance}

The US Supreme Court Lucia v. SEC ${ }^{101}$ decision is key, as it consolidates the role of administrative judges instituting proceedings within specialised independent

Warren, E. Real change: turning up the heat on non-bank lenders. The Huffington Post, 3 September 2009 .

${ }^{101}$ Lucia et al. v. Securities Exchange Commission. US Supreme Court decision. June 2018. 
agencies such as the SEC. The decision reflects on the power of administrative law judges and provides clarification on their status. The Court resolved that administrative Law Judges at the SEC are 'officers of the United States' rather than 'mere employees' and therefore need to be subject to the Appointment Clause (i.e., appointed by the president or a person with delegated power). The Supreme Court recognises that administrative judges have an important role that needs to be appointed according to a higher standard procedure in the US administration, rather than using simpler contractual means that could embed fewer guarantees in the process.

According to the Court, SEC's administrative judges carry great responsibility and exercise significant authority pursuant to the laws of the United States (e.g., take testimony, conduct trials, rule on the admissibility of evidence and have the power to enforce compliance with discovery orders, important functions that judges exercise with significant discretion). Contrary to other specialised agencies, the SEC can decide not to review the judge's decision, and when it does so, the judge's decision becomes final and is deemed the action of the SEC. The SEC judge has, undoubtedly, discretion in its role and has enforcement power. ${ }^{102}$

This precedent should inspire the inclusion of specialised administrative judges in European authorities for aspects in which they hold direct powers of supervision and enforcement. Administrative judges of the highest qualification, as per the precedent in Lucia v. SEC, improve the quality and reputation of those agencies. At the same time, such a specialised administrative and judicial body represents a competitive advantage in any given regulatory field and notably in the case of emerging markets such as crypto-finance, where general courts' judges around the globe may lack specialised knowledge and may not yet be familiar with DLT systems.

\subsubsection{Regulatory Decentralisation as a Guarantee for Independence}

The global regulatory framework design for regulating crypto-assets and for the protection of consumers and investors from crypto-finance risks should be a decentralised model that promotes competition in cooperation, the so-called coopetition. Supranational regulatory bodies representing global leaders should define international regulatory standards on crypto-finance risks and opportunities, as for instance IOSCO starts to do, leaving the implementation in the hands of each jurisdiction's regulator. In this way, the different regulatory bodies would cooperate to achieve the internationally agreed-upon standards while competing in terms of implementation strategies and thus promoting regulatory innovation. This coopetition has proven a very powerful tool for countervailing capture and/or

102 See Lucia v. SEC. Harvard Law Review, 287. 1 May 2019. 
deliberated inaction from regulators, as centralised structures are more vulnerable to these deviations.

The US Supreme Court Watters v. Wachovia Bank ${ }^{103}$ decision (2007) is the crowning of a pre-emption trend ${ }^{104}$ initiated under the George W. Bush administration to prevent states from any regulatory or supervisory intervention in the banking sphere. This case is a good illustration of the risks of a centralised supervisory and regulatory approach and how it could incentivise corruption and laisser-faire behaviour.

Wachovia Mortgages, a subsidiary entity of Wachovia Bank in North Carolina, offered mortgages in Michigan and in the rest of the United States. Subsidiary entities were under the control and supervision of the federal administration. However, Michigan statutory regulation imposes the obligation for mortgage brokers and subsidiary entities to register at the State Office of Insurance and Financial Services (OIFS) of Michigan. Linda Watters, a commissioner of the OIFS, was in charge of the supervision and of handling complaints from financial consumers referred to subsidiary entities registered in Michigan, with power limited to complaints that were not properly addressed by the federal authority. Watters requested information from Wachovia Mortgages on some of those cases, and the entity replied that the commissioner had no supervisory powers to initiate any investigation because such powers had been pre-empted by the federal administration. After this incident, commissioner Watters withdrew Wachovia Mortgages' authorisation to operate as a mortgage lender in Michigan.

The federal administrations with competences over lending activities were, on one side, the Fed with competences referred to direct supervision of federal banks, financial consumer protection and regulatory powers for transparency in credits. ${ }^{105}$ In addition, in 1994, the Home Ownership and Equity Protection Act (HOEPA) granted absolute power to the Fed to regulate for the prevention of fraud in lending contracts. On the other side, the Office of the Comptroller of the Currency (OCC) was in charge of the surveillance of currency transactions.

Traditionally, consumer protection was a state's domain, as the state's administration is closer to consumers and states' respective laws allowed for the supervision of financial institutions within each state. However, this changed under Greenspan's presidency in the Fed. He believed that capitalist markets without restrictions create wealth levels that stimulate a more civilised existence. ${ }^{106}$ In parallel, the OCC,

103 See Ballbe, M., Martinez, R., Cabedo, Y. La crisis financiera causada por la deregulation de derecho administrativo americano. In book Administración y justicia: un análisis jurisprudencial. Coords. Garcia de Enterría, E., Alonso, R. Madrid, Civitas, Vol. 2. 2012.

104 Refers to the federal government enacting legislation on a subject matter and precluding the state from enacting laws on the same subject.

105 See the Truth in Lending Act of 1968.

106 Greenspan, A. International Financial Risk Management. Federal Reserve Board. 19 November 2002. Cit. in Ballbe, M., Martinez, R., Cabedo, Y. (2012). 
under the presidency of Dugan, also started a race to the bottom, aimed at attracting banks regulated by states' agencies to the federal scope of the OCC. To achieve this, the OCC, an administration financed directly by the fees of the banks it supervises and notoriously conflicted, took a lenient approach, deciding not to initiate investigations against banks. Moreover, the OCC appeared in proceedings initiated by states' regulatory agencies (amicus brief) to support financial entities against the allegations of such agencies.

Not surprisingly, during this period, financial entities directly regulated by the federal administration grew rapidly in number, and major banks such as JP Chase, HSBC or Bank of Montreal switched from state to federal banks. These transfers alone translated into an increase of 15 per cent of OCC's total budget income. As the Congressional Report on Regulatory Reforms highlighted in 2009 ,

Fairness should have been addressed though better regulation of consumer financial products. If the excesses in mortgage lending had been curbed by even the most minimal consumer protection laws, the loans that were fed into the mortgage backed securities would have been choked off at the source, and there would have been no 'toxic assets' to threaten the global economy. ${ }^{107}$

Instead, the OCC joined Wachovia Bank against the OIFs.

The Supreme Court decision, published in 2007 (just before the start of the financial crisis), declared that the supervision of abusive conduct against consumers was a monopoly of the federal administration. It evidenced that the Supreme Court might not had known the magnitude of the frauds and abuses taking place in the mortgage market in the United States, nor to which extent federal supervisory bodies were captured. It was only after the crisis exploded when the Supreme Court changed the precedent and in Cuomo v. Clearinghouse $e^{108}$ (2009) overruled the pre-emption of States' powers, in favour of the competences of states for financial consumers' protection. Definitely, centralisation by preemption of regulatory powers made the capture of regulators easier and left citizens unprotected.

Following the same line, another recent example of the countervailing power of a decentralised regulatory model is the case of manipulation of the LIBOR, ${ }^{109}$ the benchmark that should reflect the price at which London-based financial entities borrow money and which indirectly sets the interest rates that apply to credits and loans. After the revelation of collusive practices on its fix by an article in the Wall Street Journal, ${ }^{110}$ European and UK authorities remained indifferent

107 The special report on regulatory reform of the Congressional oversight panel, January 2009.

108 Supreme Court US. Cuomo, Attorney General of New York v. Clearing House Association, L.L.C., et al. No o8-453. April 2009.

109 On this case, see Ballbe, M.; Cabedo, Y. (2013) and (2012).

11 Mollenkamp, C., Whitehouse, M. Study casts doubt on key rate. WSJ analysis suggests banks may have reported flawed interest data for libor. The Wall Street Journal. 29 May 2008. 
and took no action. It was only after competing authorities in Canada, Switzerland, Tokyo and the United States initiated a formal investigation when the European Commission reacted. Again, international competition among regulators and peer-to-peer pressure proved the best way to foster regulatory action. 
